\title{
THE GENUS RHYNCHARRHENA (ASCLEPIADACEAE)
}

\author{
K. L. WILSON
}

(Accepted for publication 11.9.1979)

\begin{abstract}
Wilson, K. L. (National Herbarium of New South Wales, Royal Botanic Gardens, Sydney, Australia 2000) 1980. The genus Rhyncharrhena (Asclepiadaceae). Telopea 2 (I): 35-39.-The nomenclatural history and the relationships of Rhyncharrhena are discussed. The genus is regarded as an Australian endemic and the new combination $R$. linearis (Decne.) K. L. Wilson is made for the single species recognized.
\end{abstract}

The genus Rhyncharrhena F. Muell. was described in 1859 but has since been regarded by most authors as a synonym of Pentatropis Wight \& Arn. or (erroneously) as a synonym of Doemia R. Br. (Daemia sphalm. auct.). Even Mueller himself apparently had doubts about its status: he (1882a) accepted the synonymizing of the genus under Pentatropis by Bentham (1869) and named a new species Pentatropis kempeana F. Muell., at the same time remarking that the species was "with the other species of this genus readily transferable to Daemia.' Later that same year he (Mueller 1882b) transferred to Doemia the four species that he recognized. In this he was again following Bentham, who (in Bentham \& Hooker 1876) commented that Pentratropis (including Rhyncharrhena) was scarcely distinct from Doemia. However, as pointed out by Brown (1907), Doemia R. Br. is a synonym of Pergularia L., which is a genus quite distinct from both Pentatropis and Rhynchar hena.

The main distinguishing features of these three genera are set out in Table 1. The species of all three are herbaceous twining perennials.

Most Australian Flora-writers up to the present time have used Pentatropis, as did Bentham (1869) in Flora Australiensis, although some, e.g. Moore \& Betche (1893), have used Doemia. The writing of the Flora of Central Australia, under the auspices of the Australian Systematic Botany Society, called for reconsideration of the status of Rhyncharrhena and the four species that have been recognized therein.

Such an examination had already been undertaken by the late Dr S. T. Blake in his studies of the family Asclepiadaceae. He concluded that Rhynchar hena deserved recognition as a genus separate from Pentatropis and annotated material accordingly in various Australian herbaria, but unfortunately he never published on the subject.

Bullock (1955) gave a resumé of the nomenclatural history of Pentatropis, stating that he considered that genus to consist of two species, $P$. capensis (L. f.) Bullock (P. microphylla (Roxb.) Wight \& Arn.) and P. spiralis (Forssk.) Decne., and that 'several Australian species and one from New Guinea .. . should be referred to another genus'. That other genus is Rhyncharrhena, as shown by his subsequent comments (Bullock 1965), when he selected $R$. atropurpurea as the lectotype for the genus.

Despite its lack of recognition in Australian Floras, Rhyncharhena seems a well-characterized genus within the Asclepiadaceae, readily distinguished from the Afro-Asian Pentatropis by the linear-revolute leaves (as pointed out by Bentham, 1869) and by the form of the corona, as well as by the other characters set out in Table 1. It seems to be confined to Australia, despite Bullock's mention of a New Guinea species of Rhyncharrhena. I have seen no specimens of Pentatropis novoguineensis Valeton but, from the corona features mentioned in the brief diagnosis given by Valeton (1907), this species belongs in Pentatropis rather than in Rhyncharrhena, and so has not been considered further here. 
As well as reviewing the generic status of Rhyncharrhena, it has been necessary to consider specific limits within the genus. Four supposed species that may be assigned to Rhyncharrhena have been described: $R$. atropurpurea F. Muell., R. quinquepartita F. Muell., Pentatropis linearis Decne., and P. kempeana F. Muell. These were based on specimens from Queensland, New South Wales, Western Australia, and the Northern Territory respectively, so there has been little attempt by regional Flora-writers to compare them, apart from Black (1957) who considered three of them and then commented that 'better acquaintance with these desert plants may prove that they are forms of a variable species'. Separation of the species of Rhyncharrhena has been on the basis of degree of division of the corolla, pubescence of the corolla lobes, follicle size, and slight differences in the corona. These characters (especially the degree of development of the inner corona appendages) do vary slightly in the specimens I have seen, but there is no clear or coherent pattern of variation. I consider this variation to be consistent with what could be expected in a single widespread but scattered species. Vegetatively, specimens from all parts of the range are very similar.

Accordingly, I am treating Rhyncharrhena as consisting of one rather variable species, $R$. linearis, which is spread throughout the drier regions of mainland Australia. The necessary specific combination is here made.

All specimens cited have been seen unless otherwise stated.

TABLE 1

Distinguishing features of Pentatropis, Pergularia and Rhyncharrhena.

\begin{tabular}{|c|c|c|c|}
\hline Feature & Pentatropis & Pergularia & Rhyncharrhena \\
\hline Leaves & $\begin{array}{l}\text { ovate with acute or } \\
\text { obtuse apex (mucronate) } \\
\text { base rounded or sub- } \\
\text { cordate; somewhat fles- } \\
\text { hy; margins not revolute. }\end{array}$ & $\begin{array}{l}\text { ovate with acute to } \\
\text { acuminate apex; base } \\
\text { cordate; not fleshy; } \\
\text { margins not revolute. }\end{array}$ & $\begin{array}{l}\text { linear to oblong, with } \\
\text { acute apex; base long- } \\
\text { tapering; not fleshy; } \\
\text { margins usually revolute. }\end{array}$ \\
\hline Stems .. & $\begin{array}{l}\text { pubescent, becoming } \\
\text { glabrous with age. }\end{array}$ & $\begin{array}{l}\text { pubescent, prickly or } \\
\text { hispid. }\end{array}$ & $\begin{array}{l}\text { glabrous to minutely } \\
\text { pubescent. }\end{array}$ \\
\hline $\begin{array}{l}\text { Unit } \\
\text { inflorescences. }\end{array}$ & umbel-like; subsessile. & $\begin{array}{l}\text { umbel-like to raceme- } \\
\text { like; long-pedunculate. }\end{array}$ & $\begin{array}{l}\text { umbel-like; } \\
\text { pedunculate. }\end{array}$ \\
\hline Corolla & rotate. & $\begin{array}{l}\text { salver-form to funnel- } \\
\text { form. }\end{array}$ & $\begin{array}{l}\text { broad-campanulate to } \\
\text { rotate. }\end{array}$ \\
\hline Corolla-lobes .. & puberulous within. & densely pilose within. & $\begin{array}{l}\text { glabrous to puberulous } \\
\text { within. }\end{array}$ \\
\hline Corona & single. & double. & double. \\
\hline Follicle & fusiform; glabrous. & $\begin{array}{l}\text { ovoid; echinate with long } \\
\text { soft bristles. }\end{array}$ & fusiform; glabrous. \\
\hline Distribution & $\begin{array}{l}\text { Africa to Asia and } \mathrm{New} \\
\text { Guinea. }\end{array}$ & Africa to Indo-China. & Australia. \\
\hline Illustrations & fig. la,b. & fig. $l \mathrm{c}, \mathrm{d}$. & fig. $2 a, b$. \\
\hline
\end{tabular}


Wilson, Rhyncharrhena (Asclepiadaceae)

37
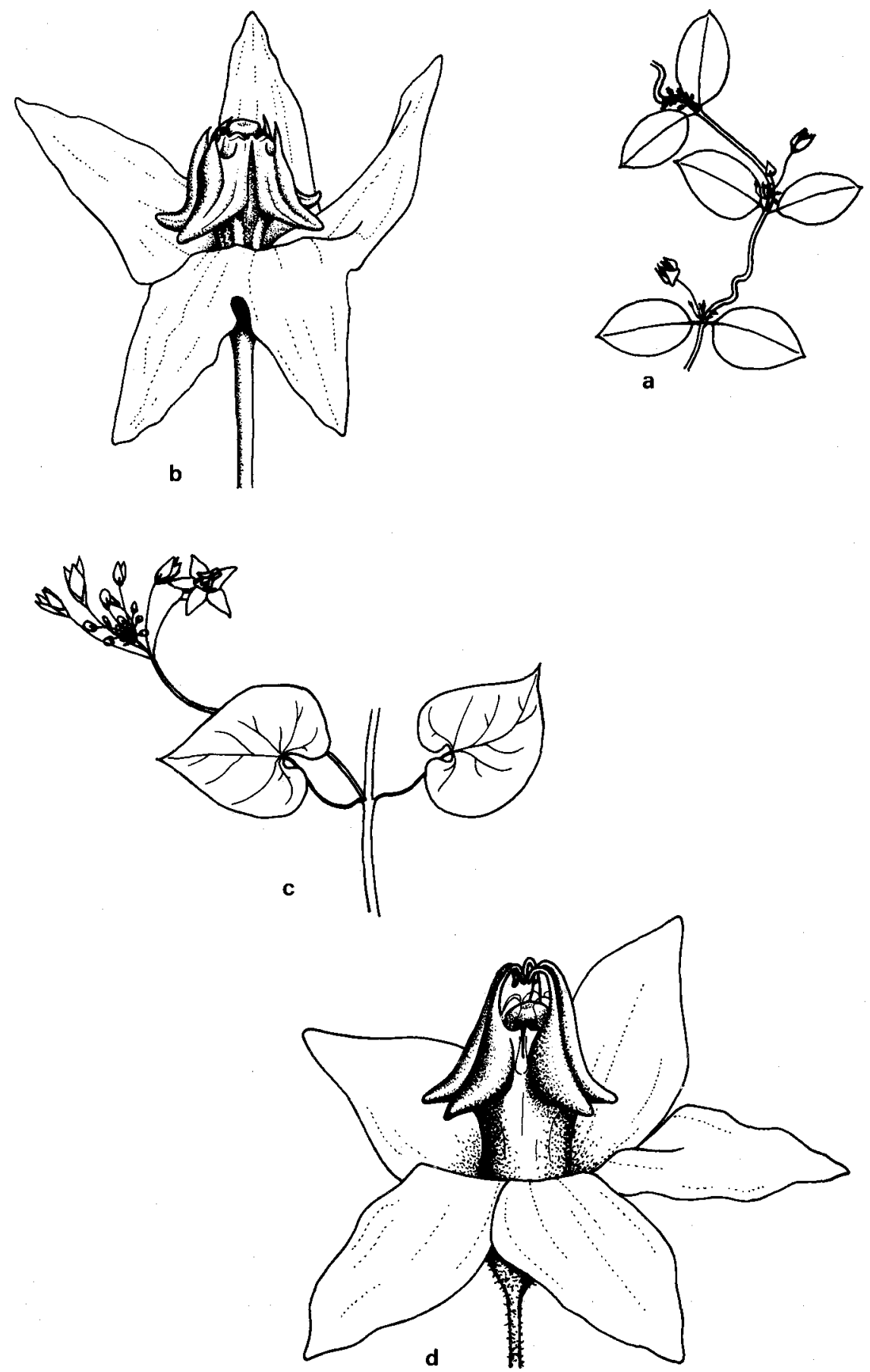

Fig. 1-Pentatropis capensis (L. f.) Bullock. (a) Portion of a branch $\times \frac{2}{3}$; (b) Flower $\times$ c. 8; from Wight 1545. Pergularia daemia (Forssk.) Chiov. (c) Portion of a branch $\times 2$; (d) Flower $\times$ c. 3; from Scheffler 21 . 

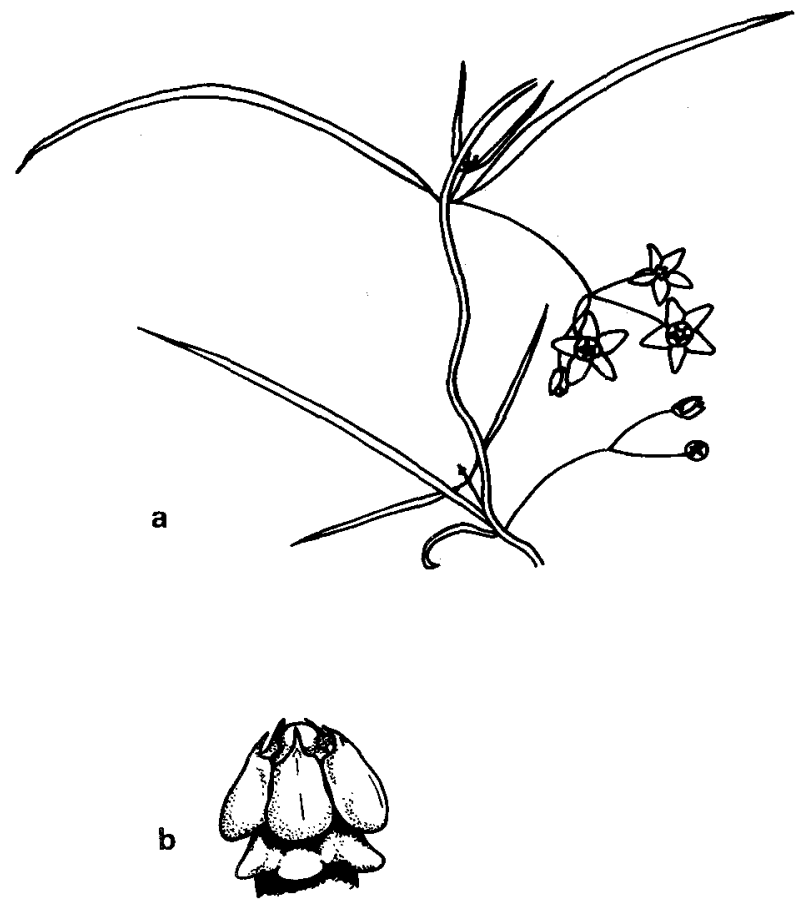

Fig. 2-Rhyncharrhena linearis (Decne.) K. L. Wilson. (a) Portion of a branch $\times \frac{2}{3}$; (b) Corona $\times$ c. 8 ; from McKee 8674 .

Rhyncharrhena linearis (Decne.) K. L. Wilson, comb. nov.

Basionym: Pentatropis linearis Decne. in Candolle, Prodr. 8: 536 (1844).

Holoty Pe: Swan River, Drummond 667 (G-not seen). ISOTYPE: MEL.

Synonymy: R. atropurpurea F. Muell., Fragm. 1: 128 (1859).-Holotype: 'in virgultis ad flumina Suttor et Dawson', Mueller 11.1856 (MEL 87148).

R. quinquepartita F. Muell., Fragm. 1: 128 (1859).--Holotype: 'in fruticatis [sic] deserti ad flumina Murray et Darling', Dallachy 10.1858 (MEL 87149).

Pentatropis kempeana F. Muell., S. Sci. Rec. 2: 172 (1882).-Holotype: 'near the Finke River,' Kempe 1882 (MEL 87146).

Selected Specimens Seen: Queensland: Mitchell: 16 miles [26 km] NW. of Longreach, Davidson 308, 12.1952 (BRI); Springvale, Clemens 5.1946 (BRI 216825); "Warrillilaba", Edwards (BRI 216826). Warrego: Charleville, Silcock S1l1, 4.1969 (BRI); $3 \mathrm{~km} \mathrm{NNW.} \mathrm{of}$ "Hillview", Purdie 6430, 5.1977 (BRI); "Gilruth Plains", Cunnamulla, McKee 10342, 4.1963 (NSW). Maranoa: "Bendena", W. of Bollon, Holland SWQS 1283, 7.1952 (CANB).

New South Wales: North Western Plains: Yathong Nature Reserve, Canning 3677, 11.1973 (NSW); Nyngan, Boorman NSW 143632, 8.1903 (NSW); Double Peak, Bäuerlen 3085, 2.1904 (BRI, NSW). South Western Plains: "Morton Court", $1 \mathrm{~km}$ W. of Euabalong West, Cunningham \& Milthorpe 5373, 2.1978 (NSW). North Far Western Plains: "Ravendale", NE. of Broken Hill, Cunningham 733, 5.1973 (NSW). South Far Western Plains: c. $58 \mathrm{~km}$ NNW. of Balranald, Crisp 1731, 11.1975 (NSW). 

(MEL).

VICTORIA: McCrackens Paddock, $2 \frac{1}{2}$ miles [4 km] NNE. of Red Cliffs, Henshall 5.1968

Northern Territory: $65 \mathrm{~km} \mathrm{SSW}$. of The Granites, Latz 704, 7.1970 (BRI, NT); 7 miles [11 km] S. Yuendumu, Peterson NT 36181, 4.1972 (NT); Haasts Bluff Reserve, Cleland 9.1957 (AD 97215152); Stuart Highway, 53 miles [85 km] N. of Alice Springs, Nelson 1671, 4.1968 (NT); Finke R., Kempe 1883 (MEL 87145); 2 miles [3 km] ENE. Ayers Rock, Latz 4121, 8.1973 (AD, NT); c. $20 \mathrm{~km} \mathrm{W.} \mathrm{of} \mathrm{Curtin} \mathrm{Springs,} \mathrm{Munir} \mathrm{5120,} \mathrm{8.1973} \mathrm{(AD).}$

South Australia: Ernabella, Tindale \& Hackett 6.1933 (BRI 216827); c. $3 \mathrm{~km} \mathrm{~N}$. of Carl Dam tank, Commonwealth Hill Station, c. $120 \mathrm{~km}$ WNW. of homestead, Lay 530, 8.1971 (AD); Malbooma Outstation, c. $1 \mathrm{~km}$ S. of Lyons railway siding, Weber 2754, 9.1971 (AD); c. $25 \mathrm{~km}$ NE. of Maralinga, Shearer 10, 2.1972 (AD); Curriewerloo, Anderson (BRI 216829); Morroo Mine, c. 20 miles [30 km] W. of Lake Frome, Greenwood NSW 143629, 10.1915 (NSW).

Western Australia: $1.5 \mathrm{~km}$ N. of Sandy Point Outcamp, Dirk Hartog I, George 11540, 9.1972 (PERTH); "Mt Augustus" Station, Wittwer 1113, 8.1973 (PERTH); "Woolen", c. $345 \mathrm{~km}$ SE. of Carnarvon, Ashby 2565, 8.1968 (AD); 14 Mile Creek, Lake Violet, Bennet 7.1941 (BRI, PERTH); near White Cliffs HS., E. of Laverton, George 4533, 6.1963 (PERTH); near Elder Creek, 2 miles [3 km] W. of Warburton Mission, George 3926, 8.1962 (PERTH); 8 miles [13 km] SW. of Three Springs on Eneabba road, Chapman 10.1978 (PERTH); Coolgardie, Gardner 1746, 9.1922 (BRI, PERTH); 3-4 miles [5-6 km] above Northam, Salasoo 438, 10.1949 (NSW); Fraser Range, Helms NSW 143625, 10.1891 (NSW).

\section{ACKNOWLEDGEMENTS}

I am indebted to the Directors of the following herbaria for sending specimens on loan or for making facilities available to me whilst visiting their institutions: AD, BRI, CANB, MEL, NT, PERTH.

Dr Jocelyn Powell kindly made a preliminary examination of specimens in MEL. The figures were drawn by Mr David Mackay.

\section{REFERENCES}

Bentham, G. (1869). 'Flora Australiensis.' Vol. 4. (Lovell Reeve \& Co.: London). Bentham, G., \& Hooker, J. D. (1876). 'Genera Plantarum.' Vol. 2, pt 1. (Lovell Reeve \& Co.: London).

Black, J. M. (1957). 'Flora of South Australia.' Second edition, pt 4. (Govt. Printer: Adelaide).

Brown, N. E. (1907). The Genus Pergularia. Kew Bull.: 323-325.

Bullock, A. A. (1955). Notes on African Asclepiadaceae VI. Kew Bull. 10: 265-292.

Bullock, A. A. (1965). Nomenclatural Notes XVI. Kew Bull. 19: 199-204.

Moore, C., \& Betche, E. (1893). 'Handbook of the Flora of New South Wales.' (Govt. Printer: Sydney).

Mueller, F. (1859). 'Fragmenta Phytographiae Australiae.' Vol. 1. (Govt. Printer: Melbourne).

Mueller, F. (1882a). Definitions of some new Australian plants. S. Sci. Rec. 2: $171-172$.

Mueller, F. (1882b). 'Systematic Census of Australian Plants.' Vol. 1. (McCarron, Bird \& Co.: Melbourne).

Valeton, T. (1907). Plantae novae papuanae. Bull. Dép. Agric. Indes Néerl. 10. $72 \mathrm{pp}$. 